\title{
ANTIMICROBIAL EFFECT OF SAGE (SALVIA OFFICINALIS L.) AND ROSEMARY (ROSMARINUS OFFICINALIS L.) ESSENTIAL OILS ON MICROBIOTA OF CHICKEN BREAST
}

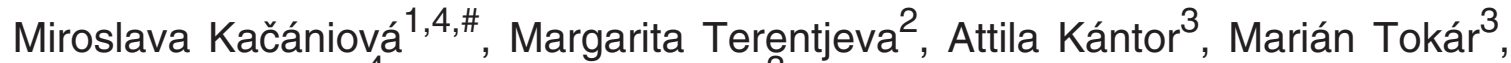 \\ Czeslaw Puchalski ${ }^{4}$, and Eva Ivanišová ${ }^{3}$ \\ ${ }^{1}$ Department of Microbiology, Faculty of Biotechnology and Food Sciences, Slovak University of Agriculture, Nitra SK-94176, SLOVAKIA \\ ${ }^{2}$ Institute of Food, Environmental Hygiene, Faculty of Veterinary Medicine, Latvia University of Agriculture, Jelgava LV-3004, LATVIA \\ ${ }^{3}$ Department of Plant Storage and Processing, Faculty of Biotechnology and Food Sciences, Slovak University of Agriculture, \\ Nitra SK-94176, SLOVAKIA \\ ${ }^{4}$ Faculty of Biology, Agriculture, Department of Bioenergy Technologies, University of Rzeszow, Rzeszow PL-35601, POLAND \\ \# Corresponding author, miroslava.kacaniova@uniag.sk
}

Communicated by Aivars Bērziṇš

The aim of the study was to evaluate the antimicrobial effect of sage and rosemary essential oils (EO) on microbiota of fresh chicken breast. Sample treatments were stored without packaging, vacuum-packaged, vacuum-packaged with EDTA $1.5 \% \mathrm{v} / \mathrm{W}$, sage and rosemary EO treatment $0.2 \% \mathrm{~V} / \mathrm{w}$. Assessment of food quality was done by anaerobic plate count (APC), and Enterobacteriaceae, lactic acid bacteria ( $L A B)$ and Pseudomonas spp. counts a period of 16 days of storage at $4 \pm 0.5^{\circ} \mathrm{C}$. Bacterial species were identified with a MALDI TOF MS Biotyper. Antimicrobial activity of isolates against both EO were tested. The APC varied from $2.97 \mathrm{log} C F U / g$ to $6.81 \mathrm{log}$ CFU/g, LAB from $2.35 \mathrm{log} C F U / g$ to $3.36 \mathrm{log} C F U / g$ and Enterobacteriaceae from $0.00 \mathrm{log} C F U / g$ on day 0 to $4.77 \log C F U / g$ with the highest counts on day 16 and in control unpackaged samples. Pseudomonas spp. was found only on days 0, 4, 8, and 12, with counts from 0.00 log CFU/g on day 16 to $2.89 \log$ CFU/g on day 4 in control unpackaged samples. APC were represented by Staphylococcus and Kocuria, $L A B$ with Lactobacillus and Enterobacteriaceae with Buttiauxella, Escherichia, Hafnia, Serratia and Yersinia. The Pseudomonas genus was represented by ten species. The best antimicrobial effect on APC, Enterobacteriaceae, LAB and Pseudomonas was achieved by application of EO. The results suggest the potential use of Salvia officinalis $L$. and Rosmarinus officinalis $L$. EOs as natural food preservatives and potential sources of antimicrobial ingredients in the food industry.

Key words: chicken breast, sage and rosemary essential oils, ethylenediaminetetraacetic acid, vacuum-packaging, bacteria.

\section{INTRODUCTION}

Poultry processing industries and researchers are eager to develop new techniques to minimise microbial growth and improve the microbiological quality of meat, including fresh chicken meat. Nowadays, increasing consumers concerns on side effects of chemical preservatives have resulted in a demand for application of natural preservatives in food and hence the use of natural preservatives has become more popular (Chouliara et al., 2008; Economou et al., 2009; Bazargani-Gilani et al., 2015). Recently, research has intensified on production of essential oil (EO) as additions to food and edible coatings, which are intended to extend the shelf life of foods (Lu et al., 2010; Fernández-Pan et al., 2014; Bazargani-Gilani et al., 2015; Raeisi et al., 2015).
Different plants have been used for production of EO and extracts for application in food processing, the pharmaceutical industry and the perfumery sector. EO and extracts not only exhibit natural aromas and flavours, but can have medicinal effect as well (Friedman et al., 2002). The genus Rosmarinus or Rosemary of the Lamiaceae family is a plant used for EO production. The Rosmarinus genus comprises of three species, however, Rosmarinus officinalis L. is the most productive and has been widely cultivated since antiquity as a herb, garden plant, and a source of EO (Porte et al., 2000). EO of rosemary has been used in various industry sectors and has been commercialised because of its antibacterial, antioxidant, antifungal, and anti-inflammatory activity. The application of rosemary EO in pest control products has been reported (Koul et al., 2008; Derwich et al., 2011). 
The antimicrobial activity of Salvia officinalis has been recognised for decades. The antimicrobial effect has been associated with the presence of 1,8-cineole, thujone and camphor (Longaray Delamare et al., 2007). Recently, antimicrobial effect of sage extract has been shown experimentally. Dry sage leaves have been used, and still are used, as a traditional remedy for many diseases (Beheshti-Rouy et al., 2015). Possible application of rosemary and salvia EO in the food industry for treatment of meat and improvement of microbiological quality of products is an area of interest.

The aim of our study was to evaluate the antimicrobial effect of sage (Salvia officinalis L.) and rosemary (Rosmarinus officinalis L.) essential oil on microbiota of fresh chicken breast, in comparison to the effect of application of other meat treatment methods.

\section{MATERIALS AND METHODS}

Essential oil preparation and analysis. The medicinal plants for EO production were donated by established growers. EOs were distilled in a large-scale distillation apparatus specifically designed for aromatic and medicinal plants. The apparatus consisted of the main distillatory apparatus, a steam condenser, steam boiler and apparatus for purifying the used water. There were two types of equipment - HV3000 with height of $5250 \mathrm{~mm}$, width of $2180 \mathrm{~mm}$ and container for 200 to $250 \mathrm{~kg}$ of dried plant material and HV-300 with height of $3400 \mathrm{~mm}$, width $1300 \mathrm{~mm}$ and container for 40 to $50 \mathrm{~kg}$ of dried plant material. Chemical analysis of the essential oils was carried out with a Hewlett-Packard 5890/5970 GC-MSD system.

Sampling and preparation of samples. Fresh chicken breast meat (ca. $300 \mathrm{~g}$, skinless and boneless fillet) was purchased from a local poultry processing plant within $1 \mathrm{~h}$ after slaughter and transferred to the laboratory of Slovak University of Agriculture, Nitra, Slovakia, in insulated polystyrene boxes on ice. The chicken meat was kept at $4{ }^{\circ} \mathrm{C}$ until the testing was initiated. For treatment of samples, EDTA (Invitrogen, USA), sage and rosemary EOs (Calendula, Nova Lubovna, Slovakia) were transferred onto meat with a micropipette to cover completely the surface of meat. Concentration of $1.5 \% \mathrm{v} / \mathrm{w}$ of EDTA $\left(\left(\mathrm{C}_{10} \mathrm{H}_{14} \mathrm{~N}_{2} \mathrm{O}_{8} \cdot \mathrm{Na}_{2} \cdot 2 \mathrm{H}_{2} \mathrm{O}\right), 99.5 \%\right.$ purity, analytical grade $)$ and $0.2 \% \mathrm{v} / \mathrm{w}$ of rosemary (Rosmarinus officinalis L.) and sage (Salvia officinalis L.) EOs were used. Each sample was packed immediately after treatment and kept at $4 \pm 0.5{ }^{\circ} \mathrm{C}$ for 16 days. A vacuum packaging machine type VB-6 (RM Gastro, Czech Republic) was used for packaging.

Microbiological analysis. An amount of $10 \mathrm{~g}$ of chicken breast was transferred into a sterile stomacher bag contain-

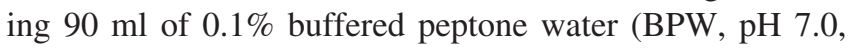
Oxoid code CM0509, Basingstoke, UK) and homogenised for $60 \mathrm{~s}$ in a stomacher at room temperature. Sampling was carried out on $0,4,8,12$ and 16 days after initiation of the experiment. Replication was six samples (Table 1).
Table 1

CHICKEN MEAT TREATMENT METHODS APPLIED IN THE PRESENT STUDY

\begin{tabular}{|c|c|}
\hline Treatment & Description \\
\hline $\mathrm{AC}$ & $\begin{array}{l}\text { Control samples: fresh chicken breast meat was packed into a } \\
\text { polyethylene bag and stored aerobically at } 4{ }^{\circ} \mathrm{C}\end{array}$ \\
\hline VPC & $\begin{array}{l}\text { Control samples: fresh chicken breast meat was packed into a } \\
\text { polyethylene bag and vacuum stored at } 4{ }^{\circ} \mathrm{C}\end{array}$ \\
\hline VPEC & $\begin{array}{l}\text { Control samples: fresh chicken breast meat was treated with } \\
\text { EDTA solution of } 1.50 \% \text { w/w for } 1 \mathrm{~min} \text {, packed into a poly- } \\
\text { ethylene bag and vacuum stored at } 4{ }^{\circ} \mathrm{C}\end{array}$ \\
\hline $\mathrm{VP}+\mathrm{S}$ & $\begin{array}{l}\text { Treated samples: fresh chicken breast meat was treated with } \\
\text { sage oil of } 0.20 \% \mathrm{v} / \mathrm{w} \text { concentration for } 1 \mathrm{~min} \text {, packed into a } \\
\text { polyethylene bag and vacuum stored at } 4{ }^{\circ} \mathrm{C}\end{array}$ \\
\hline $\mathrm{VP}+\mathrm{R}$ & $\begin{array}{l}\text { Treated samples: fresh chicken breast meat was treated with } \\
\text { rosemary oil of } 0.20 \% \mathrm{v} / \mathrm{w} \text { concentration for } 1 \mathrm{~min} \text {, packed } \\
\text { into polyethylene bag and vacuum stored at } 4{ }^{\circ} \mathrm{C}\end{array}$ \\
\hline
\end{tabular}

Serial decimal dilutions of the obtained $0.1 \%$ BPW suspensions were made. Amounts of $0.1 \mathrm{ml}$ of serial dilution were spread on the surface of agar plates. For anaerobic plate counts (APC), plate count agar (PCA, Merck code 1.05463, Darmstadt, Germany) was inoculated and the plates were incubated at $30{ }^{\circ} \mathrm{C}$ for $72 \mathrm{~h}$ in anaerobic conditions. For detection of Enterobacteriaceae, the sample suspension was spread onto Violet Red Bile Glucose Agar (Oxoid code CM $485)$ and inoculated agars were incubated at $37^{\circ} \mathrm{C}$ for $24 \mathrm{~h}$. Lactic acid bacteria (LAB) were determined on Man Rogosa Sharpe agar (Oxoid code CM 361) after incubation at $25{ }^{\circ} \mathrm{C}$ for 120 h. Pseudomonas spp. were determined on Cetrimide Fucidin Cephaloridine agar (Oxoid code CM 559, supplemented with SR 103, Basingstoke, UK) after incubation at $25^{\circ} \mathrm{C}$ for $48 \mathrm{~h}$.

Identification of microbiota with a MALDI TOF MS Biotyper. Qualitative analysis of microbial isolates was performed with a MALDI-TOF Mass Spectrometry (Bruker Daltonics, Germany). Isolates from the agar were transferred into $300 \mu \mathrm{l}$ distilled water. Then, a quantity of $900 \mu \mathrm{l}$ of ethanol was added and the tubes with bacterial suspension in water were centrifuged for $2 \mathrm{~min}$ at $14000 \mathrm{npm}$. The supernatant was discarded and the pellet was centrifuged repeatedly. After the remaining ethanol was removed, the pellet was allowed to dry. An amount of $10 \mu \mathrm{l} 70 \%$ formic acid was mixed with the pellet and a $10 \mu \mathrm{l}$ acetonitrile was added. The tubes were centrifuged for $2 \mathrm{~min}$ at $14000 \mathrm{npm}$ and $1 \mu \mathrm{l}$ supernatant was used for MALDI identification. Once dry, every spot was overlaid with $1 \mu \mathrm{l}$ of HCCA matrix and left to dry at room temperature before analysis. Generated spectra were analysed on a MALDI-TOF Microflex LT (Bruker Daltonics) instrument using Flex Control 3.4 software and Biotyper Realtime Classification 3.1 with BC specific software. Criteria for reliable identification were a score of $\geq 2.0$ at species level and $\geq 1.7$ at genus level (DeMarco and Burnham, 2014).

Antimicrobial activity detection with disc diffusion method. The agar disc diffusion method was used for the determination of antimicrobial activity of EOs on chicken 
meat microbiota. Briefly, a suspension of the tested microorganism in sterile water $\left(0.1 \mathrm{ml}\right.$ of $10^{5}$ cells per ml) was spread on Mueller Hinton Agar (MHA, Oxoid, code CM0337). Filter paper discs of $6 \mathrm{~mm}$ in diameter were impregnated with $15 \mu \mathrm{l} \mathrm{EO}$ and placed onto inoculated plates. Inoculated MHA plates were kept at $4{ }^{\circ} \mathrm{C}$ for $2 \mathrm{~h}$ and then incubated aerobically at $37{ }^{\circ} \mathrm{C}$ for $24 \mathrm{~h}$. The diameters of the inhibition zones were measured in millimetres. All tests were performed in triplicate.

Determination of minimum inhibitory concentration. Broth microdilution susceptibility assay was used to detect the minimum inhibitory concentration (MIC). All tests were performed in Mueller Hinton Broth (MHB, Oxoid, code CM0405) supplemented with Tween 80 detergent $(0.5 \%$ v/w). Bacterial strains were cultured overnight at $37{ }^{\circ} \mathrm{C}$ on MHA. After cultivation, the tested strains were suspended in MHB to give a final density of $10^{5} \mathrm{CFU} / \mathrm{ml}$. The tested EO solution was made in dimethyl sulphoxide (DMSO, Penta, Prague, Czech Republic). EOs dilutions from 0.75 to $100 \mu \mathrm{g} / \mathrm{ml}$ were prepared in a 96-well microtitre plate, including one growth control (MHB + Tween 80), one sterility control (MHB + Tween $80+$ test oil) and one negative control (pure DMSO) well. The plates were incubated aerobically at $37{ }^{\circ} \mathrm{C}$ for $24 \mathrm{~h}$. In case of bacterial growth the presence of a white pellet on the well bottom was observed.

For detection of inhibition of microbial growth, the well absorbance at $450 \mathrm{~nm}$ was measured in an absorbance microplate reader Biotek EL808 with shaker (Biotek Instruments, USA). The difference between the absorbance of 96microwell plates before and after each experiment was used as an estimate of growth. The measurement error for absorbance was 0.05. Eight replicates were used for determination of the MICs of the used EOs.
Statistical analysis. The mean values \pm standard deviations were calculated. Analysis of variance was performed on the basis of mean values to test for significant differences ( $p \leq$ 0.05 ) between treatments. Statistical analysis was conducted using the SAS version 9.1.

\section{RESULTS}

Chemical composition of essential oils. Chemical composition of EO of Rosmarinus officinalis L. was: $\alpha$-pinene $(12.1 \%)$, camphene $(7.8 \%), \beta$-pinene $(2.6 \%)$, limonene (12.2\%), 1,8-cineole (33.9\%), camphor $(7.2 \%)$, borneol (4.3\%), $\alpha$-terpineol (3.4\%) and boranyl acetate $(4.7 \%)$. The chemical composition of Salvia officinalis L. EO was: $\alpha$-pinene (9.4\%), 1,8-cineole (11.8\%), $\alpha$-thujone (23.9\%), $\beta$-thujone $(5.4 \%)$, camphor $(16.7 \%), \beta$-caryophyllene (5.2\%) and $\alpha$-caryophyllene $(2.6 \%)$.

Microbiological quality of the chicken meat. The APC of chicken breast varied from $2.97 \pm 0.04 \log \mathrm{CFU} / \mathrm{g}$ on day 0 to $6.81 \pm 0.02 \mathrm{log} \mathrm{CFU} / \mathrm{g}$ on day 16 for AC (Table 2). Enterobacteriaceae counts ranged from $0.00 \mathrm{log} \mathrm{CFU} / \mathrm{g}$ on day 0 to $4.77 \log \mathrm{CFU} / \mathrm{g}$ on day 16 of storage in AC samples. The lowest Enterobacteriaceae counts (0.00 log $\mathrm{CFU} / \mathrm{g}$ ) for treated samples were observed for VPEC, VP+S and $\mathrm{VP}+\mathrm{R}$ on day 16 of the experiment. Significant differences $(p \leq 0.05)$ in Enterobacteriaceae counts were found between the AC, VPC, VPEC, VP+R and VR+S treatments, however, the differences between the VPEC, VP+S and $\mathrm{VP}+\mathrm{R}$ treatments were not significant $(p \leq 0.05)$ (Table 2$)$.

The LAB counts were $2.35 \log \mathrm{CFU} / \mathrm{g}$ on day 0 to $3.36 \pm$ $0.14 \log \mathrm{CFU} / \mathrm{g}$ on day 16 in $\mathrm{AC}$ samples. Among treatments, the lowest $\mathrm{LAB}$ count $(2.45 \pm 0.32 \mathrm{log} \mathrm{CFU} / \mathrm{g})$ was observed for $\mathrm{VP}+\mathrm{S}$ on day 16 (Table 2). Significant differences in LAB counts $(p \leq 0.05)$ were found between the AC and $\mathrm{VPC}$ and $\mathrm{VP}+\mathrm{R}$ and $\mathrm{VP}+\mathrm{S}$ treatments.

Table 2

MICROBIOLOGICAL QUALITY OF CHICKEN MEAT AFTER APPLICATION OF FIVE MEAT TREATMENT METHODS

\begin{tabular}{|c|c|c|c|c|c|c|c|c|c|c|}
\hline \multirow[t]{3}{*}{ Day } & \multicolumn{5}{|c|}{ APC } & \multicolumn{5}{|c|}{ Enterobacteriaceae } \\
\hline & \multicolumn{5}{|c|}{ Bacterial count $(\log \mathrm{CFU} / \mathrm{g})$} & \multicolumn{5}{|c|}{ Bacterial count $(\log \mathrm{CFU} / \mathrm{g})$} \\
\hline & 0 & 4 & 8 & 12 & 16 & 0 & 4 & 8 & 12 & 16 \\
\hline $\mathbf{A C}$ & $2.97 \pm 0.04$ & $3.84 \pm 0.07$ & $4.35 \pm 0.35$ & $5.79 \pm 0.06$ & $6.81 \pm 0.02$ & 0 & 0 & $4.11 \pm 0.15$ & $4.72 \pm 0.10$ & $4.77 \pm 0.10$ \\
\hline VPC & $2.97 \pm 0.04$ & $3.58 \pm 0.22$ & $4.59 \pm 0.26$ & $5.70 \pm 0.04$ & $6.75 \pm 0.04$ & 0 & 0 & $3.68 \pm 0.84$ & $3.67 \pm 0.89$ & $3.62 \pm 0.29$ \\
\hline VPEC & $2.97 \pm 0.04$ & $3.21 \pm 0.11$ & $3.94 \pm 0.11$ & $4.70 \pm 0.05$ & $5.72 \pm 0.06$ & 0 & 0 & 0 & $0.38 \pm 0.94$ & 0 \\
\hline $\mathbf{V P + S}$ & $2.97 \pm 0.04$ & $3.43 \pm 0.10$ & $3.49 \pm 0.47$ & $4.26 \pm 0.06$ & $5.62 \pm 0.13$ & 0 & 0 & 0 & 0 & 0 \\
\hline $\mathbf{V P + R}$ & $2.97 \pm 0.04$ & $3.53 \pm 0.17$ & $3.86 \pm 0.48$ & $4.54 \pm 0.28$ & $5.70 \pm 0.08$ & 0 & 0 & 0 & 0 & 0 \\
\hline \multirow[t]{3}{*}{ Day } & \multicolumn{5}{|c|}{ Lactic acid bacteria (LAB) } & \multicolumn{5}{|c|}{ Pseudomonas spp. } \\
\hline & \multicolumn{5}{|c|}{ Bacterial count $(\log \mathrm{CFU} / \mathrm{g})$} & \multicolumn{5}{|c|}{ Bacterial count $(\log \mathrm{CFU} / \mathrm{g})$} \\
\hline & 0 & 4 & 8 & 12 & 16 & 0 & 4 & 8 & 12 & 16 \\
\hline $\mathbf{A C}$ & $2.35 \pm 0.30$ & $2.70 \pm 0.46$ & $3.28 \pm 0.60$ & $2.85 \pm 1.02$ & $3.36 \pm 0.14$ & $2.36 \pm 0.25$ & $2.89 \pm 0.05$ & $2.72 \pm 0.53$ & $2.83 \pm 0.55$ & $2.94 \pm 0.48$ \\
\hline VPC & $2.35 \pm 0.30$ & $2.46 \pm 0.41$ & $3.75 \pm 0.15$ & $3.28 \pm 0.90$ & $3.26 \pm 0.13$ & $2.36 \pm 0.25$ & $2.86 \pm 0.09$ & $2.33 \pm 0.20$ & $2.53 \pm 0.18$ & $2.72 \pm 0.17$ \\
\hline VPEC & $2.35 \pm 0.30$ & $2.28 \pm 0.34$ & $2.39 \pm 0.26$ & $2.61 \pm 0.22$ & $2.61 \pm 0.51$ & $2.36 \pm 0.25$ & 0 & 0 & 0 & 0 \\
\hline $\mathbf{V P + S}$ & $2.35 \pm 0.30$ & $2.20 \pm 0.24$ & $2.17 \pm 0.24$ & $2.29 \pm 0.06$ & $2.45 \pm 0.32$ & $2.36 \pm 0.25$ & 0 & 0 & 0 & 0 \\
\hline$V P+R$ & $2.35 \pm 0.30$ & $2.08 \pm 0.56$ & $2.12 \pm 0.10$ & $2.17 \pm 0.13$ & $2.57 \pm 0.52$ & $2.36 \pm 0.25$ & 0 & 0 & 0 & 0 \\
\hline
\end{tabular}


Pseudomonas spp. counts varied from $2.36 \mathrm{log} \mathrm{CFU} / \mathrm{g}$ on day 0 to $2.94 \log \mathrm{CFU} / \mathrm{g}$ on day 16 in the $\mathrm{AC}$ treatment. The lowest value $(0.00 \mathrm{log} \mathrm{CFU} / \mathrm{g})$ of $\mathrm{LAB}$ in treated samples on day 16 occurred in the VPEC, VP+S and VP+R treatments (Table 2). There were no significant differences between Pseudomonas spp. counts in VPEC and VP+R $(p \leq 0.05)$ treatments. Significant differences $(p \leq 0.05)$ were found between AC and VPEC, AC and VP+S, VPEC and $\mathrm{VPC}$, VPC and $\mathrm{VP}+\mathrm{S}$, and $\mathrm{VP}+\mathrm{R}$ and $\mathrm{VP}+\mathrm{S}$ treatment pairs.

Identification of microbiota with a MALDI TOF MS Biotyper. Altogether, two genera (Staphylococcus and Kocuria) were identified from APC plates. Within the Staphylococcus genus, S. warneri was the most frequently isolated species, while S. pasteuri $(11.76 \%)$ was isolated less frequently. There were no significant differences in abundance of Kocuria kristinae (11.76\%) and Kocuria rhizophila (11.76\%) (Table 3). Among LAB, only Lactobacillus spp. were isolated; L. reuteri $(50.00 \%)$ was more abundant than L. salivarius $(25.00 \%)$ and L. acidophilus $(25.00 \%)$. The genus Pseudomonas was represented by ten species, of which P. fluorescens (14.29\%), P. synxantha (14.29\%) and P. gessardii $(14.29 \%)$ were the most abundant. Enterobacteriaceae included Buttiauxella, Escherichia, Hafnia, Serratia and Yersinia, and Serratia fonticola (21.43\%) and Hafnia alvei $(21.43 \%)$ were the most abundant (Table 3).

Antimicrobial activity. The results on antibacterial activity of EOs assessed by disc diffusion method against the bacterial isolates from meat revealed that EOs were the most effective against $L$. reuteri and $Y$. enterocolitica, with inhibition zones of 10.00 and $12.33 \mathrm{~mm}$ for S. officinalis, and 12.33 and $12.67 \mathrm{~mm}$ for $R$. officinalis, respectively (Table 4). Determination of minimal inhibitory concentration of EOs showed that the best antimicrobial activity of $S$. officinalis was against $L$. salivarius and $B$. izardii with MIC50 $=3.125$ and MIC90 $=6.25 \mu \mathrm{g} / \mathrm{ml}$, respectively. $L$. salivarius and $B$. izardii were the most sensitive to $R$. officinalis EO activity, with MIC50 = 6.25 and MIC90 = $12.50 \mu \mathrm{g} / \mathrm{ml}$ (Table 4).

\section{DISCUSSION}

GC-MSD analysis of sage and rosemary EOs identified seven and nine components representing $75.00 \%$ and $88.20 \%$ of the total contents of the EOs, respectively. Previous studies (Raal et al., 2007; Jiang et al., 2011; Verma et al., 2015) showed similar phytochemical properties of rosemary EOs to those observed in our study. The compounds 1,8-cineole, thujone, camphor, and viridiflorol were reported in rosemary EOs originating from Ukraine and India (Raal et al., 2007, Verma et al., 2015). The main components of rosemary EO in another study (Jiang et al., 2011) were 1,8-cineole, $\alpha$-pinene, camphor, camphene and $\beta$-pinene.

Microbiological testing results showed that the quality of chicken meat used in the present study was good. However,
Table 3

IDENTIFICATION OF BACTERIA ISOLATED FROM CHICKEN MEAT AFTER TREATMENT

\begin{tabular}{|c|c|c|}
\hline Species & $\begin{array}{c}\text { No. of bacterial } \\
\text { colonies/ No. of } \\
\text { samples }\end{array}$ & Percentage \% \\
\hline \multicolumn{3}{|l|}{ Lactic acid bacteria (LAB) } \\
\hline Lactobacillus salivarius & $1 / 9$ & 25.00 \\
\hline Lactobacillus reuteri & $2 / 9$ & 50.00 \\
\hline Lactobacillus johnsonii & $1 / 9$ & 25.00 \\
\hline \multicolumn{3}{|l|}{ Pseudomonas spp. } \\
\hline Pseudomonas fluorescens & $2 / 9$ & 14.29 \\
\hline Pseudomonas synxantha & $2 / 9$ & 14.29 \\
\hline Pseudomonas chlororaphis & $1 / 9$ & 7.14 \\
\hline Pseudomonas gessardii & $2 / 9$ & 14.29 \\
\hline Pseudomonas libanensis & $2 / 9$ & 14.29 \\
\hline Pseudomonas orientalis & $1 / 9$ & 7.14 \\
\hline Pseudomonas veronii & $1 / 9$ & 7.14 \\
\hline Pseudomonas extremorientalis & $1 / 9$ & 7.14 \\
\hline Pseudomonas agarici & $1 / 9$ & 7.14 \\
\hline Pseudomonas lundensis & $1 / 9$ & 7.14 \\
\hline \multicolumn{3}{|l|}{ Anaerobic plate count (APC) } \\
\hline Staphylococcus warneri & $6 / 9$ & 35.29 \\
\hline Staphylococcus epidermidis & $5 / 9$ & 29.41 \\
\hline Staphylococcus pasteuri & $2 / 9$ & 11.76 \\
\hline Kocuria kristinae & $2 / 9$ & 11.76 \\
\hline Kocuria rhizophila & $2 / 9$ & 11.76 \\
\hline \multicolumn{3}{|l|}{ Enterobacteriaceae family } \\
\hline Serratia fonticola & $3 / 9$ & 21.43 \\
\hline Hafnia alvei & $3 / 9$ & 21.43 \\
\hline Serratia liquefaciens & $1 / 9$ & 7.14 \\
\hline Buttiauxella gaviniae & $2 / 9$ & 14.29 \\
\hline Buttiauxella izardii & $1 / 9$ & 7.14 \\
\hline Yersinia enterocolitica & $1 / 9$ & 7.14 \\
\hline Buttiauxella noackiae & $2 / 9$ & 14.29 \\
\hline Escherichia coli & $1 / 9$ & 7.14 \\
\hline
\end{tabular}

changes in bacterial counts were observed up to an APC of $6.81 \pm 0.02 \log \mathrm{CFU} / \mathrm{g}$ on day 16 of experiment in the $\mathrm{AC}$ treatment. Our findings indicated that untreated chicken meat stored in an anaerobic environment was the most subjected to spoilage. The absence of Enterobacteriaceae $(0.00$ $\log \mathrm{CFU} / \mathrm{g}$ on day 0 ) supported the assessment of quality of chicken meat as satisfactory. Enterobacteriaceae on raw beef, lamb, pork, poultry products and offal indicate the efficiency of hygiene during processing (Zeitoun et al., 1994; Pokorny et al. 2001; Khanjari et al., 2013). Pseudomonas spp. and $\mathrm{LAB}$ counts of $2.35 \pm 0.30$ and $2.36 \pm 0.25$ also showed that the quality of meat was acceptable. Pseudomonas spp. and LAB are associated with meat spoilage, and the presence of these bacteria can accelerate deterioration of quality of meat (Oussalah et al. 1996; Frantianni et al., 2010). 
ANTIMICROBIAL ACTIVITY OF ESSENTIAL OILS AGAINST BACTERIAL ISOLATES ORIGINATED FROM CHICKEN MEAT AFTER TREATMENT

\begin{tabular}{|c|c|c|c|c|c|c|}
\hline \multirow{3}{*}{$\begin{array}{c}\text { EOs } \\
\text { Microorganisms }\end{array}$} & \multicolumn{2}{|c|}{ Diameter of inhibition zone in $\mathrm{mm}$} & \multicolumn{4}{|c|}{ Minimal inhibition concentration in $\mu \mathrm{g} / \mathrm{ml}$} \\
\hline & \multirow[t]{2}{*}{ S. officinalis } & \multirow[t]{2}{*}{ R. officinalis } & \multicolumn{2}{|c|}{ S. officinalis } & \multicolumn{2}{|c|}{ R. officinalis } \\
\hline & & & MIC 50 & MIC 90 & MIC 50 & MIC 90 \\
\hline L. salivarius & $3.00 \pm 1.00$ & $6.00 \pm 1.00$ & 3.125 & 6.25 & 6.25 & 12.50 \\
\hline L. reuteri & $10.00 \pm 1.00$ & $12.33 \pm 2.52$ & 6.25 & 12.50 & 12.50 & 25.00 \\
\hline L. johnsonii & $5.00 \pm 0.00$ & $4.67 \pm 0.58$ & 25.00 & 50.00 & 25.00 & 50.00 \\
\hline P. synxantha & $4.66 \pm 0.58$ & $4.00 \pm 0.57$ & 25.00 & 50.00 & 12.50 & 25.00 \\
\hline P. chlororaphis & $4.33 \pm 0.58$ & $2.33 \pm 0.57$ & 12.50 & 25.00 & 25.00 & 50.00 \\
\hline P. gessardii & $2.33 \pm 0.58$ & $7.66 \pm 1.53$ & 6.25 & 12.50 & 12.50 & 25.00 \\
\hline P. libanensis & $4.33 \pm 0.58$ & $9.00 \pm 1.00$ & 25.00 & 50.00 & 25.00 & 50.00 \\
\hline P. orientalis & $2.33 \pm 0.58$ & $8.67 \pm 0.58$ & 50.00 & 100.00 & 50.00 & 100.00 \\
\hline P. extremorientalis & $4.33 \pm 0.58$ & $3.00 \pm 1.00$ & 6.25 & 12.50 & 25.00 & 50.00 \\
\hline P. agarici & $7.33 \pm 0.58$ & $3.00 \pm 1.00$ & 25.00 & 50.00 & 25.00 & 50.00 \\
\hline$P$. lundensis & $4.33 \pm 0.58$ & $3.00 \pm 1.00$ & 25.00 & 50.00 & 25.00 & 50.00 \\
\hline S. warneri & $2.00 \pm 1.00$ & $5.33 \pm 0.58$ & 50.00 & 100.00 & 25.00 & 50.00 \\
\hline S. epidermidis & $4.66 \pm 0.58$ & $5.00 \pm 1.00$ & 50.00 & 100.00 & 25.00 & 50.00 \\
\hline S. pasteuri & $6.67 \pm 1.53$ & $5.33 \pm 0.57$ & 6.25 & 12.50 & 12.50 & 25.00 \\
\hline K. kristinae & $9.67 \pm 1.53$ & $5.67 \pm 1.53$ & 50.00 & 100.00 & 50.00 & 100.00 \\
\hline K. rhizophila & $4.67 \pm 0.58$ & $5.00 \pm 1.00$ & 50.00 & 100.00 & 50.00 & 100.00 \\
\hline S. fonticola & $4.33 \pm 0.58$ & $7.33 \pm 0.58$ & 25.00 & 50.00 & 25.00 & 50.00 \\
\hline H. alvei & $6.00 \pm 1.00$ & $4.33 \pm 0.58$ & 25.00 & 50.00 & 12.50 & 25.00 \\
\hline S. liquefaciens & $4.33 \pm 0.58$ & $4.33 \pm 0.58$ & 25.00 & 50.00 & 12.50 & 25.00 \\
\hline Y. enterocolitica & $12.33 \pm 1.53$ & $12.67 \pm 1.15$ & 6.25 & 12.50 & 12.50 & 25.00 \\
\hline B. noackiae & $4.67 \pm 0.58$ & $3.33 \pm 0.58$ & 25.00 & 50.00 & 25.00 & 50.00 \\
\hline E. coli & $8.67 \pm 0.58$ & $4.33 \pm 0.58$ & 25.00 & 50.00 & 12.50 & 25.00 \\
\hline
\end{tabular}

MIC, minimum inhibitory concentration

The results showed significant differences in bacterial contamination between the samples treated with different methods and especially with the EO treatments. Inhibition of $\mathrm{APC}$ and Enterobacteriaceae in the $\mathrm{VP}+\mathrm{S}$ and $\mathrm{V}+\mathrm{R}$ treatments, in comparison with AC and VPC treatments, was likely due to the antibacterial effects of the vacuum packaging and treatment with sage and rosemary EOs. Rosemary EOs, which contain ursolic acid, phenolic acids, flavones, and other compounds, can inhibit the growth of E. coli, $P$. aeruginosa, $P$. vulgaris, $B$. subtilis, $S$. aureus, and $K$. pneumonia (Prabuseenivasan et al., 2006). Miladinović and Miladinović (2000) reported that EO from sage leaves exhibits antimicrobial activity against $B$. subtilis, St. aureus ATCC 6538, E. coli, Salmonella enterica serovar Enteritidis and Aspergillus niger. However, Ntzimani et al. (2010) described the presence of Enterobacteriaceae on semi-cooked chicken meat samples after treatment with EDTA and rosemary EO, indicating the possible survival of the microorganisms.
Significantly lower counts $(p \leq 0.05)$ of LAB in VP+R and $\mathrm{VP}+\mathrm{S}$ treatments than in $\mathrm{AC}$ and VPEC treatments indicated that treatment with EOs had significant effect on growth of LAB in chicken meat. The effect of rosemary EO observed in the present report was in agreement with Zaika et al. (1983) who showed a reduction of $4 \mathrm{log} \mathrm{CFU} / \mathrm{g}$ in LAB populations after the addition of $4 \mathrm{~g} / \mathrm{l}(0.4 \%)$ of oregano EO. Differences in the activity of EOs may be attributed to the type of food and composition of EO and this should be taken into consideration when the EOs effect is evaluated (Zaika et al. 1983; Burt, 2004). The results of our study on a combined effect of EOs and VP are in agreement with Chouliara et al. (2007), who described the inhibitory effect of EO meat treatment on microbial growth in chicken meat.

Reduction of the Pseudomonas spp. population in VTEC meat had been described to occur after EDTA treatment, which increases sensitivity to antibacterial agents against 
which Pseudomonas spp. are normally resistant (Ntzimani et al., 2011). Bioactive components of EOs possess relatively weak activity against Pseudomonas spp., due to differences in cell wall composition between Gram-negative and Gram-positive bacteria (Burt, 2004). Inhibitory effect of EOs on growth of Pseudomonas spp. associated with meat spoilage was observed in a study on the effect of 60 different EOs in concentrations from 0.003 to $0.8 \%$ (v/w) (Oussalah et al. (2006).

The application of EOs of Salvia officinalis $0.2 \%$ and Rosemarinus officinalis $0.2 \%$ had strong antimicrobial effect on growth of APC and Enterobacteriaceae, LAB and Pseudomonas spp. It is important to point out that not all EOs exhibit inhibitory activity. Anise, eugenol, coriander, clove, oregano, spearmint and thyme oils were found to be effective in inhibiting spoilage flora in meat products and to cause marked initial reduction in the number of recoverable cells (Tsigarida et al., 2000; Skandamis and Nychas, 2001; Kačániová et al., 2016). Ntzimani et al. (2010) reported that vacuum-packaged coated chicken samples with the addition of rosemary EO showed a 7-day shelf-life extension. Borneol from sage and rosemary had an inhibitory effect against Gram-positive and Gram-negative bacteria at 2\% while the concentrations of $0.3 \%$ and $0.5 \%$ were bacteriostatic and bactericidal for Gram-positive bacteria (Bajpai et al., 2008).

\section{CONCLUSION}

Our results show that the combined use of vacuum-packing and application of EOs treatment can extend the shelf-life of the product up to 16 days at $+4{ }^{\circ} \mathrm{C}$. The identified inhibitory effect of sage and rosemary oil on Enterobacteriaceae in vacuum packed chicken breast meat was potential use in provision of good microbiological quality of the product.

\section{ACKNOWLEDGMENTS}

The study was supported by the European Community project No. 26220220180: Building Research Centre "AgroBioTech" and by grant of Slovak Research and Development Agency No. VEGA 1/0411/17.

\section{REFERENCES}

Bajpai, V.K., Rahman, A., Kang, S. C. (2008). Chemical composition and inhibitory parameters of essential oil and extracts of Nandina domestica Thunb to control food-borne pathogenic and spoilage bacteria. Int. J. Food Microbiol., 125 (2), 117-122.

Bazargani-Gilani, B., Aliakbarlu, J., Tajik, H. (2015). Effect of pomegranate juice dipping and chitosan coating enriched with Zataria multiflora Boiss essential oil on the shelf-life of chicken meat during refrigerated storage. Innovative Food Sci. Emerg. Technol., 29, 280-287.

Beheshti-Rouy, M., Azarsina, M., Rezaie-Soufi, L., Yousef Alikhani, M., Roshanaie, G., Komaki, S. (2015). The antibacterial effect of sage extract (Salvia officinalis) mouthwash against Streptococcus mutans in dental plaque: A randomized clinical trial. Iran J. Microbiol., 7 (3), 173-177.

Burt, S. (2004). Essential oils: Their antibacterial properties and potential applications in foods-a review. Int. J. Food Microbiol., 94 (3), 223-253.
Chouliara, E., Karatapanis, A., Savvaidis, I. N., Kontominas, M. G. (2007). Combined effect of oregano essential oil and modified atmosphere packaging on shelf-life extension of fresh chicken breast meat, stored at $4{ }^{\circ} \mathrm{C}$. Food Microbiol., 24 (6), 607-617.

Chouliara, E., Badeka, A., Savvaidis, I., Kontominas, M. G. (2008). Combined effect of irradiation and modified atmosphere packaging on shelf-life extension of chicken breast meat: Microbiological, chemical and sensory changes. Eur. Food Res. Technol., 226, 877-888.

Derwich, E., Benziane, Z., Chabir, R. (2011). Aromatic and medicinal plants of Morocco: Chemical composition of essential oils of Rosmarinus officinalis and Juniperus phoenicea. Int. J. Appl. Biol. Pharm. Technol., 2 (1), 145-153.

Economou, T., Pournis, N., Ntzimani, A., Savvaidis, I. (2009). Nisin-EDTA treatments and modified atmosphere packaging to increase fresh chicken meat shelf-life. Food Chem., 114, 1470-1476.

Fernández-Pan, I., Carrión-Granda, X., Maté, J.I. (2014). Antimicrobial efficiency of edible coatings on the preservation of chicken breast fillets. Food Control, 36, 69-75.

Jiang, Y., Wu, N., Fu, Y.-J., Wang, W., Luo, M., Zhao, C.-J., Zu, Y.-G., Liu, X.-L., (2011). Chemical composition and antimicrobial activity of the essential oil of rosemary. Environ. Toxicol. Pharmacol., 32, 63-68.

Fratianni, F., De Martino, L., Melone, A., De Feo, V., Coppola, R., Nazzaro, F. (2010). Preservation of chicken breast meat treated with thyme and balm essential oils. J. Food Sci., 75 (8), M528-M535.

Kačániová, M., Terentjeva, M., Puchalski, C., Petrová, J., Hutková, J., Kántor, A., Mellen, M., Čubon, J., Haščík, P., Kluz, M., Kordiaka, R., Kunová, S. (2016). Microbiological quality of chicken thighs meat after application of essential oils combination, EDTA and vaccum packing. Potravinarstvo, 10 (1), 107-113.

Khanjari, A., Karabagias, I. K., Kontominas, M. G. (2013). Combined effect of N,O-carboxymethyl chitosan and oregano essential oil to extend shelf life and control Listeria monocytogenes in raw chicken meat fillets. $L W T-$ Food Sci. Technol., 53 (1), 94-99.

Koul, O., Walia, S., Dhaliwal, G.S. (2008). Essential oils as green pesticides: Potential and constraints. Biopesticides Int., 4 (1), 63-84.

Longaray Delamare, A. P., Moschen-Pistorello, I. T., Artico, L., Atti-Serafini, L., Echeverrigaray, S. (2007). Antibacterial activity of the essential oils of Salvia officinalis L. and Salvia triloba L. cultivated in South Brazil. Food Chem., 100, 603-608.

Lu, F., Ding, Y., Ye, X., Liu, D. (2010). Cinnamon and nisin in alginate-calcium coating maintain quality of fresh northern snakehead fish fillets. $L W T$ Food Sci. Technol., 43, 1331-1335.

Miladinović, D., Miladinović, L. (2000). Antimicrobial activity of essential oil of sage from Serbia. Facta Univers. Ser. Physics, Chem. Technol., 2 (2), 97-100.

Ntzimani, A. G., Giatrakou, V. I., Savvaidis, I. N. (2010). Combined natural antimicrobial treatments (EDTA, lysozyme, rosemary and oregano oil) on semicooked coated chicken meat stored in vacuum packages at $4{ }^{\circ} \mathrm{C}$ : $\mathrm{Mi}$ crobiological and sensory evaluation. Innov. Food Sci. Emer. Technol., 11 (1), 187-196.

Ntzimani, G., Giatrakou, V.I., Savvaidis, I.N. (2011). Combined natural antimicrobial treatments on a ready-to-eat poultry product stored at 4 and $8{ }^{\circ} \mathrm{C}$ A. Poultry Sci., 90 (4), 880-884.

Oussalah, M., Caillet, S., Saucier, L., Lacroix, M. (2006). Antimicrobial effects of selected plant essential oils on the growth of a Pseudomonas putida strain isolated from meat. Meat Sci., 73 (2), 236-244.

Pokorny, J., Yanishlieva, N., Gordon, M. (2001). Antioxidants in Food. Cambrige: Woodhead publishing Ltd., 400 pp.

Porte, A., Godoy, R., Lopes, D., Koketsu, M., Torquilho, S. L., Torquilho, H. (2000). Essential oil of Rosmarinus officinalis L. (rosemary) from Rio de Janeiro, Brazil. J. Essent. Oil Res., 12, 577-580.

Prabuseenivasan, S., Jayakumar, M., Ignacimuthu, S. (2006). In vitro antibacterial activity of some plant essential oils. BMC Complem. Alter. Med., 6, 39 . 
Raal, A., Orav, A., Arak, E. (2007). Composition of the essential oil of Salvia officinalis L. from various European countries. Nat. Product Res., 21 (5), 406-411.

Raeisi, M., Tajik, H., Aliakbarlu, J., Mirhosseini, S. H., Hosseini, S. M. H. (2015). Effect of carboxymethyl cellulose-based coatings incorporated with Zataria multiflora Boiss. essential oil and grape seed extract on the shelf life of rainbow trout fillets. LWT Food Sci. Technol., 64, 898-904.

Skandamis, P., Nychas, G.J. (2001). Effect of oregano essential on microbiological and physicochemical attributes of minced meat stored in air and modified atmospheres. J. Appl. Microbiol., 91 (1), 1011-1022.

Tsigarida, E., Skandamis, P., Nychas, G.J.E. (2000). Behaviour of Listeria monocytogenes and autochthonous flora on meat stored under aerobic, vac- uum and modified atmosphere packaging conditions with or without the presence of oregano essential oil at $5{ }^{\circ} \mathrm{C}$. J. Appl. Microbiol., 89 (6), 901-909.

Verma, R. S., Padalia, R. C., Chauhan, A. (2015). Harvesting season and plant part dependent variations in the essential oil composition of Salvia officinalis L. grown in northern India. J. Herb. Med., 5 (3), 165-171.

Zaika, L. L., Kissinger, J. G., Wasserman, A. E. (1983). Inhibition of lactic acid bacteria by herbs. J. Food Sci., 48 (5), 1455-1459.

Zeitoun, A. A. M., Debevere, J. M., Mossel, D. A. A. (1994). Significance of Enterobacteriaceae as index organisms for hygiene on fresh and treated poultry, poultry treated with lactic acid and poultry stored in a modified atmosphere. Food Microbiol., 11 (2), 169-176.

Received 2 October 2016

Accepted in the final form 18 October 2017

\section{SALVIJAS (SALVIA OFFICINALIS L.) UN ROZMARĪNA (ROSMARINUS OFFICINALIS L.) ĒTERISKO EL,LUU ANTIMIKROBIĀLĀ IEDARBĪBA UZ CĀḶA FILEJAS MIKROFLORU}

Pētījuma mērḳis bija noteikt salvijas un rozmarīna èterisko eḷlu antimikrobiālo ietekmi uz cāḷa filejas mikrofloru. Eksperimentiem tika sagatavoti sekojoši cāḷa filejas paraugi: 1) vakuuma iepakojumā; 2) vakuuma iepakojumā ar EDTA (1,5\% v/m); 3) vakuuma iepakojumā pēc apstrādes ar salvijas un rozmarīna èteriskajām eḷlām $(0,2 \% \mathrm{v} / \mathrm{m})$. Savukārt cāḷa filejas paraugs bez iepakojuma izmantots kā kontroles paraugs. Sagatavotos cāḷu filejas paraugus uzglabāja 16 dienas $4 \pm 0,5{ }^{\circ} \mathrm{C}$. mikrobioloğiskās kvalitātes izmainas tika analizētas, nosakot anaerobo, Enterobacteriaceae dzimtas, pienskābes un Pseudomonas spp. baktēriju skaitu. Baktēriju sugas tika identificētas, lietojot MALDI TOF MS Biotyper. Eksperimentu gaitā kontroles paraugā tika konstatēta intensivāka mikrooganismu attīstība. Eksperimentā kopumā anaerobais baktēriju skaits mainījās no 0 . uzglabāšanas dienā no $2,97 \log \mathrm{KVV} \mathrm{g}^{-1}$ līdz $6,81 \mathrm{KVV} \mathrm{g}^{-1} 16$. uzglabāšanas dienā, bet pienskābes baktēriju skaits attiecīgi no 2,35 $\log \mathrm{KVV} \mathrm{g}^{-1} \operatorname{lī} \mathrm{dz} 3,36 \mathrm{KVV} \mathrm{g}^{-1}$ un Enterobacteriacea dzimtas baktēriju skaits no $0,00 \log _{\mathrm{KVV}} \mathrm{g}^{-1}$ līdz 4,77 $\log \mathrm{KVV} \mathrm{g}^{-1}$. Pseudomonas spp. baktērijas identificēja 0., 4., 8. un 12. eksperimenta dienā, un to skaits mainījās no $0,00 \mathrm{KVV}^{-1}$ 16. uzglabāšanas dienā līdz 2,89 KVV g ${ }^{-1}$ 4. uzglabāšanas dienā. Pētījumu gaitā identificēja tādas baktēriju ğintis kā Staphylococcus, Kocuria, Lactobacillus, Buttiauxella, Escherichia, Hafnia, Serratia, Yersinia un Pseudomonas. Eksperimentos izteiktāks antibaktēriālais efekts, ietekme uz mikroorganismu skaitu, konstatēta cāḷa filejas paraugos, pēc apstrādes ar èteriskajām eḷlām. Pētījuma rezultāti norāda uz iespējamo salvijas (Salvia officinalis L.) un rozmarīna (Rosmarinus officinalis L.) èterisko ellıu izmantošanu pārtikas produktu gatavošanā kā dabīgu konservantu un antimikrobiālo vielu avotu. 